\section{THE CROONIAN LECTURE ox}

\section{THE POSITION OF PATHOLOGY AMONG THE BIOLOGICAL STUDIES.}

Delivered before the Royal Society, March 16th, 1893.

By Professor RUDOLF VIRCHOW, For. Mem. R.S., Rector Magnificus of the University of Berlin, and Director of the Berlin Pathological Institute.

IT is now nearly ten years since this illustrious Society conferred on me the unexpected honour of electing me one of its Foreign Members. Not this only, but last autumn it held me worthy of a further honour in awarding me the Copley Medal -a sign of the highest recognition of my work, the significance of which far exceeds the distinctions which the changing favour of political powers is accustomed to bestow. Nevertheless, deeply as I appreciated this mark of its constant and increasing esteem, still I was not in a position to offer my thanks personally to the Society. Numerous duties, official and private, the weight of which has increased with each year, compelled me to continuous work at home, and the extension of international relations, becoming more intimate, has for a long time restricted the freedom of my movements even during the vacations.

With great indulgence, which I fully know how to appreciate, the Council has allowed me to postpone the date of my appearance in its midst. Hence, you see me only today among you, and I may tell you in person how very grateful I am to this Society, and how great an incentive to new efforts your recognition has become to me.

Who of us is not in need of friendly encouragement in the changing events of life? True happiness is not based on the appreciation of others, but on the consciousness of one's own honest labour. How otherwise should we hold our ground in the midst of the turnoil of the day? How should we preserve the hope of progress and of final victory against the attacks of opponents and the insults which are spared to no one who comes before the public? He who during a long and busy life is exposed to public opinion, certainly learns to bear unjust criticism with equanimity, but this comes only through the confidence that our cause is the best, and that some day it must triumph. Such is our hope in our wrestlings for progress in science and art; such is our hope in our struggles for civil and religious liberty, and in this hope we gradually become hardened against malicious attacks. It is a kind of immunisation which, I acknowledge, has also great drawbacks, for this hardening towards unjust attacks leads very easily to a similar indifference towards just attacks, and, owing to the tendency to contradiction rooted in the nature of human thought, it finally leads also to indifference to praise and recognition. One withdraws again and again into oneself, discontented with theworld and with oneself also ; but who can so completely retire within himself that the consciousness of the insufficiency of human thought, and that the criticisms of opponents are justified, cannot break through the crust of even the most hardened self-consciousness? Happy is he who has courage enough to keep up or regain his connections with other men, and to take part in the common work. Thrice happy he who does not lack in this work the flattering commendation of esteemed colleagues

Such were the thoughts which filled my mind, as, looking forward to the present occasion, I reviewed my own life and the history of science, or, to use another expression, the fortunes of our predecessors. How often have $I$ found myself in a state of despondency, with a feeling of depression. And the history of science-what long periods of stagnation and numerous interruptions has it not experienced owing to the victory of erroneous doctrines. What has saved me is the habit of work, which has not forsaken me even in the days of outward misfortune, that habit of scientific work which has always appeared to me as a recreation, even after wearying and useless efforts in political, social, and religious matters.

That which has saved science is identically the same; it only appears to be different because the co-operation of many is necessary to secure the advance of science; hence the exalting and consoling thought that one nation after the other comes to the front to take its share in the work. When the star of science becomes dim in one nation it rises sooner or later to yet brighter glory in another, and so one nation after another becomes the teacher of the world.

No science, more often than medicine, has gone through these waxings and wanings of brilliancy; for medicine alone of all these sciences has for more than 2,000 years found ever new homes in the course of a progress which, though often disturbed, has never been wholly arrested.

It would lead us too far to illustrate this with examples drawn from the entire past. It is enough for my present purpose to take the outlines of modern medicine as the object of our consideration. Such a sketch, cursory as it must be, ought at the same time to throw some light on the intellectual relations of both nations, English and German, for these have taken a prominent part in establishing the principles of modern medicine.

The downfall of the old medicine, the so-called humoral pathology, was brought about in the beginning of the sixteenth century. We, in Germany, are inclined to attribute to our nation a decisive rôle in this memorable struggle.

It was a man of our race, Andreas Vesalius, or from Wesel who transformed anatomy into an exact science, and who thus, at one stroke, created for medicine a solid foundation, which it has retained ever since, and, let us hope, will never again lose.

But the principal blow to the old medicine was struck by his somewhat elder contemporary Paracelsus; that charlatan yet gifted physician who removed from among the beliefs of mankind the doctrine of the four humores which, quasi-chemical in its construction, formed the basis of the old pathology. Strangely enough, he accomplished this with weapons borrowed from the armoury of the Arabs, the successors of the Greeks, and the chief representatives of the mediæval humoral pathology. From them, also, he borrowed alchemy, and at the same time the fantastic spiritualism of the East, which found a clear expression in his doctrine of the "archæus," as the determining force in all living beings.

In this way the new medicine, at its very birth, absorbed the germs of that ruinous contradiction, which, even up to this present century, has kept up the embittered strife of the schools.

To Vesalius is due the exact tendency which starts from the observation of actual conditions, and which, without going further, we may call the anatomical.

Paracelsus, who pronounced the anatomy of the dead body to be useless, and sought for the basis of life as the highest goal of knowledge, demanded "contemplation" before all else; and, just as he himself arrived in this way at the metaphysical construction of the " archæi," so he unchained among his followers a wild and absolutely fruitless mysticism.

Nevertheless there lay hidden in that "contemplation" of his a healthy kernel, which would not allow the intellectual activity which it had stirred up to come to rest. It was the idea of life which formed the ultimate problem for all future research. Strangely enough, this idea, which always existed in the popular mind, and which is in an unmistakable form present even amongst primitive nations, had been driven far into the background in scholastic medicine. Ever since the time of Hippocrates it had been the custom to use, instead of life, the obscure expression " $\phi \dot{v} \sigma$ เs" natura ; but in vain does one seek for a more exact definition of the term. To Paracelsus Nature was living, and the basis of his life was that very "archæus," a force differing from matter," and separable from it, or, as he himself expressed it, in the sense of the Arabs, a spirit, "spiritus." In the compound organism of man, the mikrokosmos, each part, according to him, had its own "archæus," but the whole was ruled by the "archæus maximus," the "spiritus rector." From this premiss has proceeded the long succession of vitalistic schools, which, in ever-changing forms, and with ever new nomen- 
clature, introduced into the notions of physicians this idea of a fundamental principle of life.

If the sagacious Georg Ernest Stahl, whose services to the development of chemistry are now acknowledged everywhere, substituted the soul for the "spiritus rector," and so created a system of animism, the last vestiges of which have disappeared from the school of Montpelier within our own time only, so also in turn did the pure vitalists build upon the dogma of specific dynamic energies, maintained so stoutly by the physicists, that notion of the vital force, the half spiritualistic and half physical character of which has contributed so much, even in our day, to puzzle and mislead men's minds.

The doctrine of the vital force found its strongest support in the "Natur-philosophie," especially in that which, on German ground, soon obtained universal sovereignty.

This summary exposition of mine has greatly anticipated the historical progress of the evolution of medicine. It is now time to pay proper homage to the great investigator who made the more exact method the ruling one, and at the same time to award to this country, which brought him forth, its important share in determining the new direction of our science.

Nearly 100 years had passed since Vesalius and Paracelsus had begun their work when William Harvey published his "Exercitatio anatomica de motu cordis et sanguinis in animalibus." Here, for the first time, the anatomical examination of living parts was carried through, in an exemplary way, according to experimental methods. All the objections that anatomy concerned itself with dead parts only were thus at once set aside; living action became the object of immediate observation, and this was done on one of the most important organs, one absolutely necessary to life, the varying activity of which constantly calls for the attention of the practical physician. Not only so, however, but a new mode of observation-the experimental method-was thus brought into use for research; a method through which a new branch of medical science, physiology, has been labouriously built up.

The influence of this one wonderful discovery of Harvey's on the ideas of men of his time and of his successors was memorable. Among the men of his time, the last support of Galenism disappeared with the proof of circulation; among his successors the comprehension of the causation of local processes dawned for the first time. Very ancient and highly difficult problems, such as inflammation, could now be attacked; a goodly piece of life also became intelligible, since one of the vital organs themselves could now be subjected to experiment, and, to the astonishment of all, the action of this organ showed itself to be an absolutely mechanical one. The revulsion of thought was so cumplete, that it has become since a difficulty hardly to be overcome to enter even in imagination into the ideas of the older physicians, to whom the circulation of the blood was unknown.

Nevertheless, in spite of such striking results, the craving of man for more complete understanding remained unsatisfied. One saw the action of the living heart, but how did it live? What was this life, the action of which one saw before one? In the heart itself the essence of life could not be recognised.

Harvey turned his attention to another object; he tried to observe the very beginnings of life in the incubated egg of the fowl and in the embryos of mammalian animals. He thereby soon arrived at the question of the significance of the egg in general, and enunciated the celebrated dictum, "Omne vivum ex ovo." Owing to the more extensive researches of modern investigators, this dictum, as is well known, proved too narrow for the whole animal kingdom, and is no longer exact when applied to plant life. Its validity for the higher animals, on the other hand, cannot be questioned, and it has formed one of the firm standpoints on which researches on sexuality and on the propagtition of life have been based. But Harvey, on account of the deficiency of his optical instruments, was unable to see that which he was labouring to discover, namely, the process of organisation as such, just as he had been unable in former timrs to see the continuity of the capillary flow. This imperfection lasted for a long time afterwards; and thus it happened that even Albrecht von Haller and John Hunter considered the formation of the area vasculosa in the incubated egg of the fowl as thecommencement of organisation, and, indeed, as the type of organisation itself. I will return to this point later on; but for the present $I$ should like first to draw your attention to a man whose importance for the further development of the doctrine of life has always appeared to me to have been uncommonly great and highly significant, but who, nevertheless, has sunk into unmerited oblivion, not only among posterity in general, but also, I think I may be allowed to say, even in the memory of his countrymen. I mean Francis Glisson, who was a contemporary of Harvey, and whose works appeared almost simultaneously with those of his more celebrated colleague; but the brilliancy of Harvey's discoveries was so great that the light which shone from Glisson's work-table almost disappeared. I rejoice that on so joyful an occasion I may recall the memory of the modest investigator, and may offer him the tribute of gratitude which science has to award him.

When, thirty-five years ago, I published my little essay on "Irritation and Irritability " I did not know much more about Glisson than what every student of medicine learns, namely, that there is in the liver a "capsula communis Glissonii," and, what was even less known, that this anatomist had written a small work on "Rachitis," which, indeed, was the first of its kind. In my own paper on this disease ${ }^{2}$ I had tried to demonstrate the circumspection and accuracy which are noticeable in this book, and which make it a typical model for all collective investigations; but even at that time I overlooked the fact that this was only the smallest merit of this wonderful man. It was only in the further course of my studies on the history of the doctrine of irritation and irritability that I made the discovery, an astonishing one to me, that the idea of irritability did not, as is generally thought, originate with Haller, but that the father of modern physiology, and the Leyden School in which he had been brought up, had borrowed this idea from Glisson. I then stumbled on a series of almost forgotten publications of this original scholar, especially his "Tractatus de naturâ substantiæ energeticæ seu de vitâ naturæ ejusque tribus primis facultatibus, perceptiva, appetitiva, et motiva," which appeared in London in 1672, and in which the ideas were further worked out, the outlines of which had already been brought forward in his "Anatomia Hepatis," published in 1654. In this work (p. 400) the newly-coined word "irritabilitas" appears, so far as I can find out, for the first time in literature. It may be noticed, by the way, that the expression "irritatio" is much older. I find it already in Celsus, but with an exclusively pathological signification. It appears, also, occasionally in later writers, and to this day it has not, speaking accurately, lost this original signification. It is otherwise with Glisson; to him, irritability is a physiological property, and irritation merely a process of life dependent on the natural faculties of living matter.

Thus he was led, through a process of contemplation, to maintain the existence of the "biarchia," the "principium vitæ," or the "biusia," the "vita substantialis vel vitæ substantia." And in order to allow of no misunderstanding as to the source of his "contemplation," he adds distinctly that this is the "archæus" of Van Helmont-the "vis plastica" of plants and animals.

In the further course of his philosophical discussions, he nevertheless is led into the same by-path, which has misled, even in the most recent times, so many learned men and even excellent observers. This is the by-path of unlimited generalisation. The human mind is only too prone to render intelligible what is unintelligible in particular phenomena, by generalising them. Just as even in recent times an attempt has been made to render consciousness intelligible by representing it merely as a general property of matter; so Glisson thought he might attribute to the active principle ("principium energeticum ") which according to him is contained in all matter, the three faculties of living matter which he considered as fundamental, namely, the facultas perceptiva, appetitiva, et motiva. All matter was sensitive, was thus stimulated to develop impulses, and moved itself as a consequence of these impulses.

It is not necessary for the purpose of our present inquiry to carry these quotations further, since they are quite, in the Paracelsian sense, contemplative in their nature; and

1 Archiv fur pathologische Anatomie und Physiologie, 1858, vol. xiv, p. 50. 
especially as, in their generalisation, they do not appear to be important for the history of advancing knowledge.

That which is full of significance for us is concerned with actual life only, in the narrower sense of analytic science. It was not the "principium energeticum " set up by Glisson, which stimulated his successors again to take up the thread of his observations, but rather this process of irritation described by him, and the fundamental faculties of living matter on which it depended. In this way he has really led up to a more exact study of the actions of life and the properties of living matter.

Unfortunately, there intervened a mistaken conception, which led his followers again into a series of most serious errors. Glisson, following on this point also the example of Van Helmont, was convinced that nerves contracted when irritated. He joined to this the idea that, through the contraction of the nerves, or even of the brain, the fluid contained in them was propelled towards the periphery.

This notion, shared by Willis and many other physicians of that time, furnishes the reason why irritability was identified with contractility. Even the great master Hermann Boerhaave, and after him his pupil Gaubius, the first special writer on general pathology, considered sensation and motion as common properties of, at all events, all the solid parts of the body. The former thought it proved that hardly a single particle of the body existed which was not sensitive and did not move; and thus it becomes comprehensible how Haller himself carried this idea that irritability had the same significance as contractility from his school days in Leyden to his professorship in Göttingen. It was in this sense that he understood the irritability of the muscles, and in the same sense he denied this property to the nerves.

This dispute about the irritability of muscles has continued far into the present century; its long duration becomes intelligible only when we bear in mind that, without the most exact knowledge of its historical development, even the very statement of the question is liable to be misunderstood.

As a matter of fact, so far as we know, the nerves are not contractile, like the muscles; on the other hand, the muscles are not only contractile, but are also irritable. Irritability and contractility are not identical, even when they occur in the same part. The nerve current, on the other hand, cannot be conpared with the blood stream; it does not consist in the movement of a fluid, but is of electrical nature, and hence there is no need for its production of a contraction of the nerve tubes.

It was also an erroneous conclusion that every irritated part contracted. Instead of contraction, secretion, or, under certain circumstances, a more vigorous nutrition may occur as the final result of irritation. Hence we use a more comprehensive term in order to express this final result, and call all forms of it "actions." While Glisson defined all "actio propria sic dicta" as "motus activus," we distinguish different kinds according to the nature of the effects, or, expressed otherwise, according to the direction of the activity (nutrition, formation, and function); but we agree with the above thinker in the opinion that no vital energy is ever set free without stimulus ; that, therefore, every action is of an irritative nature. In this irritation, according to my idea, consists the "principium dividendi," according to which we must distinguish between active and passive processes of life and in this way we gain also a basis for the fundamental division of pathological elementary processes. How much work has been necessary in order to render this conception possible. And how great, even now, is the number of our colleagues who have not fully accepted it. The reason for this difficulty is twofold.

Most of the vital actions of life, whenever they manifest themselves by visible events, are of a compound nature. As a rule, very various, at times wholly unlike, parts, each with its specific energy, combine to produce them. Not infrequently it thereby happens that in the visible sum of final effects one part behaves in an active, the other in a passive manner. It is only the most minute analysis of the phenomenon, tracing it right back to the elementary parts, which allows the total result to be resolved into its components such an analysis cannot, for the most part, be expressed in current language, except at great length. No language in the world is rich enough to possess special expressions for each such combination. Only too often we help ourselves out of the difficulty by regarding the compound phenomenon as a simple one, and by expressing its character according to some chief trait, which stands out in a commanding manner from the general picture. This is the practical difficulty.

With it, however, a theoretical difficulty is very often combined. The human mind, owing to a natural impulse, seeks in the phenomena indications of their determining cause The more complex the phenomenon, the more busy is the imagination, in order to convert it into a simple one, and to find a unitarian cause for it. So has it happened in respect to life, so in respect to disease. The course of thought followed by Glisson is opposed to such an explanation. He had no scruple in dividing the unit of life into a large number of individual lives. Although the knowledge we now possess of the arrangements of the body was absolutely foreign to him, yet he arrived quite logically at the "vita propria," the proper elementary life, of the several parts. To be sure, this expression, so far as I can see, is not to be found in his works, but occurs first in those of Gaubius; but Glisson says distinctly : ${ }^{3}$ "Quod vivit per se vivit vitam a nullâ creaturầ proter se ipsum dependentem. Hoc enim verba vivere per se sonant.'

The unitarian efforts of the following period relentlessly passed over the tendency of which I have just spoken. Some returned to the old Mosaic dictum, "the life of the body is in his blood;" others gave the nervous system, and the brain especially, the first place in their consideration. Thus once more was renewed the old struggle, which for thousands of years had divided the schools of medicine into humoral and solidar pathology. Even when we ourselves entered on scientific work, hæmato-pathologists stood in hostile attitude to neuro-pathologists.

In England, humoral pathology found a strong support in the great and legitimate authority of John Hunter. Although this distinguished practitioner never shared the one-sidedness of the later pathologists, but rather attributed to the solid parts the living principle the existence of which he assumed, nevertheless, in his investigations, the blood took precedence over all other parts as the chief vehicle of life.

One must, however, recall to mind that Hunter laid swecial stress on the fact that life and organisation are not bound to each other, since animal substances which are not organised can possess life. He started, as has already been noticed, from the erroneous conception that eggs are not organised, and that it was not till after incubation that the first act of organisation-namely, the formation of vessels-took place. He considered his "diffuse matter"-_ materia vitæ diffusa"--as the actual carrier of life; and this was to be met with not only in the solid parts, but in the blood also. This matter, according to him, existed in the brain in a remarkable degree of concentration, but its presence was quite independent of all nervous structures, as is shown by the example of the lower animals which possess no nerves. In the posthumous writings of Hunter, which Owen has collected, the very striking expression " simple life" is met with, a state most clearly to be recognised in plants and the lowest animals. This simple life was, in Hunter's view, the ultimate source of all living actions, pathological as well as physiological.

Hunter was out and out a vitalist, but his materialistic vitalism, so to speak, differed toto cxlo from the dynamic. vitalism of the German schools. If living matter existed independently of all organisation, such living matter was beyond the scope of anatomical investigation; but, on the other hand, if it were present in non-organised parts, such as an egg, it was in itself the ultimate source of the organisation which subsequently makes its appearance in these parts. Itmust, therefore, to adopt a later mode of expression, be of a plastic nature. Here Hunter's notion fell in with that of the plastic lymph, as developed by Hewson. and it was only logical that Schultzenstein applied it to the blood at last, and designated as "plasma" the material of life present in the blood. In this way the formative and nutritive matter necessary to physiological life as well as the plastic exudations occurring in diseased conditions, could be attributed to the same material-a highly satisfactory result in appearance, and one providing a most convenient basis for interpretations. The exponents of this notion had no scruples in going one step further, and in providing this material of life with a technical name. Thev

$$
3 \text { Glisson, Anatomia Ilepatis, "Ad lectorem," N. } 17 .
$$


called it "fibrin." Evidently this did not quite correspond with Hunter's ideas, for we know of no such matter, either in the egg, or in the plants, or the lower animals, as that to which he attributed simple life; but the necessities of pathology overcame all such scruples, and the plastic exudations were received as undoubted evidence that fibrin possessed the power of becoming organised. They formed, in the crasis doctrine of the Vienna school, the bright spot of this newest kind of hemato-pathology.

Wherever fibrin failed, blastemata were brought to the fore. Ever since Schwann had given the name of cytoblastema to the organising material of the egg, the way had been opened for assuming, in other places, the existence of material with this ambiguous name.

But, of course, through these steps the one simple matter of life, predicated by Hunter, was replaced by many "matters of life," and thus the entire advantage gained by the exposition of a unitary theory of life was at once lost.

Even when, finally, protoplasma was recognised as cell contents, and thus the one requisite of Hunter, namely, that the material of life must also be contained in the individual parts, appeared to be fulfilled, yet no single specific material was thereby arrived at. No one dreamed of regarding protoplasm as fibrin, and least of all did anyone consider it a simple chemical body.

By the conception of the blastema, however, there had been reawakened a thought which had occupied the minds of man from the earliest times. If a plastic matter capable of being organised really existed in the body, then the organisation of the same must present the first reliable example of epigenesis. The problem of the "generatio æquivoca," which had been fought over for so long a time, now appeared to be solved. What Harvey had taught concerning the descent from the egg was rejected concerning the descent from exudation. Several generations of young medical men have been educated in this belief. I myself remember my "epigenetic" youth, with no little regret, and I have had hard work to force my way through to the recognition of the sober truth.

Meanwhile, the attention of other bodies of inquirers had been directed to the tissues of the body. Among these, in view of their importance, the nervous tissues, and especially the mass of nervous tissues in the brain and spinal cord, rank highest.

Hunter also had acknowledged the importance of the brain, and hence called it the "materia vitæ coacervata." It was easily seen that it contained no fibrin, but experimental research showed also that neither the brain nor the spinal cord was of the same value throughout all its parts. The more accurate the experiments, the smaller became the region which, in the strictest sense, is the vital part, until Flourens limited it to one single spot, the knot of life ("nœud vital"). Was the unity of life found in this way? By no means. The brain is no more and no less vital than the heart; for life is present in the egg long before the brain and heart are formed, and all plants, together with an immense number of animals, possess neither the one nor the other. In the highly compound organism of man, the brain and spinal cord have a certain determining action on other parts necessary to life. Their disturbance may immediately be followed by the disturbance of other vital organs, and sudden death may ensue.

But the collective death of a compound animal no more implies the local death of all its special parts than the local death of some of the latter is incompatible with the collective life of the animal. As has been well said, at the death of a compound organism there is a "primum moriens," one part which first ceases to live; then follow, at long intervals sometimes, the other organs, one after the other, up to the " ultimum moriens." Hours and days may pass between the total death and the local death of the parts. The fewer nerves a part contains, the more slowly usually does it die ; I therefore consider the process of dying in the compound organism as the best illustration of the individual life of the several constituent parts, which is in its turn the first axiom necessary for the study and for the understanding of life.

A long time, however, elapsed before it was possible to return to this starting point, and to obtain a considerable number of supporters for the doctrine of the "vita propria." The attention of many observers was drawn to a totally dif- ferent side of the question. In the last decade of the past century, about the same time that John Hunter, starting from careful anatomical investigations and exact observations of surgical practice, worked out his idea of the material of life, a new system of medicine was founded in Scotland, the so-called Brownian system, which was based on quite different premisses. Brown also was a vitalist; he, too, constructed, not merely a pathological and therapeutic system of vitalism, but a physiological one, though this doctrine was dynamic in its character.

There is but little to be noticed therein of the material anatomical foundation of exact medicine. It is concerned principally with contemplations of the forces of the living organism. One can understand to some extent how this happened if one keeps in view the history of the development of this extraordinary personality. I cannot go into this here, but anyhow the remarkable fact remains that the two contemporaries-Brown and Hunter-worked near each other without it appearing from their writings that they were acquainted with one another. Brown struck out his own line and stuck to it, without troubling himself about the rest of the medical world. And yet even his first work, Elementa Medicina, had the effect of an earthquake; the whole European continent was shaken by it, and even the physicians of the recently opened New World bent under the yoke of revolutionary ideas; and in a few years the aspect of the whole field of medicine was entirely changed. True, the triumph was but short; the Brownian system disappeared as it had come-a meteor in the starry heaven of science. There would be no reason to go into it more fully had not the impulse which he had given instigated other men, and been permanently applied by them to the true service of science. This impulse was founded on the fact that irritability, or, as Brown called it, "incitability," was thus reinstated as the starting point of the theory; but, along with this, the stimuli which set living substances in action, the "potestates incitantes," were brought to the fore. In so far that stimuli produce a state of irritation ("incitatio "), or, as Brown called it later, excitement, they came to be viewed not only as the cause of health and disease, but even of life itself ; for excitement, so he said, is the true cause of life ; but, as excitement stands in a certain relation to the strength of the stimulus, a state of good health was only possible with a normal degree of stimulus, whilst an excess or a lack of stimulus brought diseased conditions in its wake. Of course excitement is dependent also on irritability, with a certain quantity of which, in the form of energy, every living being is endowed at the beginning of its life.

The division of diseases, according to the amount of vital force visible in them, into sthenic and asthenic, has never been abandoned since, though acknowledged perhaps in a less precise manner; it has sometimes been brought more prominently forward, and sometimes thrown into the background. In Germany, Schönlein was the one of all others who took this doctrine as the foundation of his opinion on special cases of disease, and for his choice of treatment.

But the application of the Brownian principles to physiology has been of far greater importance. If life itself were dependent on external stimuli, the notion of the spontaneity of vital actions, a notion still in force, must lose all significance. Certain stimuli would in that case prove to be necessary conditions of vital activity, without which life could at best be carried on in a latent form only. Certainly even for this latent life the question remained open, How does it come to pass, and in what does it practically consist? Brown avoided this ticklish question, not without great skill, by drawing the whole attention to active life and to the stimuli which call forth action. To speak openly, science has since then deflected little, or not at all, from this guiding notion. Even now we cannot say what latent life is. We simply know that through external stimuli it may be converted into active life, and hence irritability is considered by us as the surest sign of life, not of course of the general life of all matter in the sense of Glisson, but of the real and individual life of special living organisms. Brown remarked, with reason, that through irritability the living substance is differentiated from the same substance in its dead condition, or from any other lifeless matter. Nevertheless, neither 
irritability nor incitability, neither irritation nor incitation, explains the essence of the living substance, and therefore neither explains the essence of life.

In Germany the physiologists especially took up this question. Among the first was Alexander von Humboldt, who in his various writings, especially in his celebrated treatise on the irritated muscle and nerve fibre, entered into the question. In the end he held fast to the assumption of a vital force. The majority of pathologists and physicians followed in his footateps, and long and fierce controversies were necessary before, nearly half a century later, the belief in a vital force was destroyed. When Du Bois-Reymond had demonstrated the electrical current in muscle and nerve in all its characters, and, at the end of his work, had also disclosed the inadmissibility of vital force, then the venerable Humboldt formally and expressly renounced the dream of his youth, with the masterly submission of the true naturalist to the recognised natural law.

The hypothesis of a vital force of life had, however, in regard to Brown's theory, neither a positive nor a negative value. Johannes Müller rescued for general physiology, in which it has ever since kept its place, that which was valuable in Brown's system, the doctrine of the integrating life stimuli. The occasional stimuli which produce disease have found their place in etiology; their significance has become more and more sharply defined, the more accurately we have learnt to distingnish between the causes and the essences of disease, a distinction which became more difficult as the "causæ vivæ" of diseases became known in ever-increasing numbers. And now a new task has arisen, namely, to draw into our sphere of observation the life of the causative agents themselves.

The way in which pathology has tried to approach the desired goal, to fathom the living substance in its diseased conditions, has led us a great step forward. Pathological anatomy, especially, has opened this road. The more numerous its observations, and the more it penetrated into the details of the lesions, the smaller became the field of so-called general diseases. The first steps of modiæval anatomists had the effect of drawing the attention to lucal diseases. In the first and longest period, which one may define as that of Regionism, the pathological anatomists sought the cause of disease in one of the larger regions or cavities of the bodyin the head, chest, or abdomen. In the second period, ushered in by the immortal work of Morgagni, shortly before the time of which I last spoke-the time of Brown and Hunter, - they endeavoured to find in a certain region the actual organ which might be considered as the seat of disease. On this foundation arose the Parisian school of Organicism, which, until late in this century, held a dominant position in pathology. In this school, already, they recognised that not the organ, nor even a portion of it, could be the ultimate object of research. Xavier Bichat divided the organs into tissues, and showed that in the same organ sometimes one and sometimes another tissue might be the seat of disease.

From that time forward the eye of the pathological anatomist was directed chiefly to the changes in the tissues, but it soon became apparent that even the tissues are not simple substances. Since the third decade of this century, the microscope has disclosed the existence of cells, first in plants, and very soon afterwards in animals. Only living beings contain cells, and vegetable and animal cells show so much similarity of structure that one can demonstrate in them the actual product of organisation. This conviction has become general, since through our embryologists, especially through Schwann, proof has been afforded that the construction of embryonic tissues was derived from cells, also, in the highest animals and in man himself.

In the fourth decade of this century the science of pathological anatomy had already begun to be directed towards cells. These researches very soon struck on great difficulties. Many tissues, even in their developed state, appeared to contain neither cells nor their equivalents; nevertheless, I have been able to demonstrate their existence in those tissues in which their presence appeared to be most doubtful-namely, in bone and connective tissues. At the present time we are so far advanced as to be able to say that every living tissue contains cellular elements.
We go a step further even, for we require that that tissue alone should be called living in which the constant occurrence of cells can be shown.

A still greater difficulty then appeared-namely, to discover in what way new cells originated. The answer to this question had been very heavily prejudiced by the so-called cell theory of Schwann. Inasmuch as this very trustworthy investigator asserted that new cells originated from unformed matter, from " cytoblastema,' there was opened up a wide road to the old doctrine of the "generatio æquivoca," which afforded all partisans of plastic materials an easy way of reviving their dogma. The discovery of cells of connective and allied tissues gave me the first possibility of finding a cellular matrix for many new growths. One observation followed another, and I was soon in a position to give utterance to the dictum, "Omnis cellula e cellulâ."

And so at last the great gap was closed which Harvey's ovistic theory had left in the history of new growth, or, to speak more generally, in the history of animal organisation. The begetting of a new cell from a previous cell supplements the reproduction of one individual from another, of the child from the mother. The law of the continuity of animal development is therefore identical with the law of heredity, and this I now was able to apply to the whole field of pathological new formation. I blocked for ever the last loophole of the opponents, the doctrine of the specific cells of pathology, by showing that even diseased life produced no cells for which types and ancestors were not forthcoming in normal life.

These are the fundamental principles of cellular pathology. In proportion as they have become more certain, and lastly of more general value, they have also secured for themselves great importance in physiology. The cell is not only the seat and vehicle of disease, but also the seat and carrier of individual life; in it resides the "vita propria." It possesses the property of irritability, and the changes in its substance, provided these do not destroy life, produce local disease.

Disease presupposes life; should the cell die, its disease also comes to an end. Certainly, as a consequence, the neighbouring and even far distant cells may become diseased, but as regards the cell itself, the susceptibility to disease is extinguished with life.

Since the cellular constitution of plants and animals has been proved, and since cells have become recognised as the essentially living elements, the new science of biology has sprung up. It has not brought us the solution of the ultimate riddle of life, but it has provided concrete material, anatomical objects for investigation, the properties, the actions, and the passions of which we can analyse. It has put an end to the wild confusion of fantastic and arbitrary notions such as I have just mentioned; it has placed in a strong light the immeasurable importance of anatomy, even in the most delicate conditions of the body, and, lastly, it has made us aware of the close similarity of life in the highest and lowest organisms, and has thus afforded us invaluable means for comparative investigation.

Pathology has also its place, and one certainly not without honour, in this science of biology, for to pathology we are indebted for the knowledge that the opposition between. healthy and diseased life is not to be sought in a fundamental difference of the two lives, not in an alteration of the essence, but only in an alteration of the conditions.

Pathology has been released from the anomalous and isolated position which it had occupied for thousands of years. By applying its revelations not only to diseases of man, but also to those of animals, even the smallest and lowest, and to those of plants, it in the best manner helps to strengthen biological knowledge, and to narrow still more that region of the unknown which still surrounds the intimate structure of living matter. It is no longer merely applied physiology; it has become physiology itself.

Nothing has more contributed thereto than the constant scientific union which has endured for more than 300 years between English and German investigators, and to which we to-day add yet another link. May this union never be broken!

Profrasor Finkler, of Bonn, has been sent to Chicago by the German Government to organise the Section "Universities of Germany "in the World's Fair. 